\title{
RENOVATION PRIORITY RANKING BY MULTI-CRITERIA ASSESSMENT OF ARCHITECTURAL HERITAGE: THE CASE OF CASTLES
}

\author{
Barbara VODOPIVEC a, Roko ŽARNIĆ a, Jolanta TAMOŠAITIENE் ${ }^{\text {b,*, }}$ \\ Marius LAZAUSKAS ${ }^{b}$, Jana ŠELIH ${ }^{a}$ \\ ${ }^{a}$ Faculty of Civil and Geodetic Engineering, University of Ljubljana, Jamova 2, 1000 Ljubljana, \\ Slovenia \\ ${ }^{b}$ Department of Construction Technology and Management, Faculty of Civil Engineering, Vilnius \\ Gediminas Technical University, Sauletekio al. 11, LT-10223 Vilnius, Lithuania
}

Received 20 May 2013; accepted 2 December 2013

\begin{abstract}
Preservation of cultural heritage is related with high costs and required interventions generally exceed available funding. It is, therefore, necessary to prioritise renovation interventions. Multi-criteria assessment can lead to scientifically sound and informed decisions about interventions. The paper presents the results of research carried out with the purpose of establishing a multi-criteria method for the assessment of architectural heritage, specifically for castles in Slovenia. It explains the methodology used to develop the multi-criteria method. Its main elements are critical content analysis of relevant literature, comparative analysis between the Slovenian and international space, and identification of relevant criteria and sub-criteria of the decision method. The course and results of empirical research, based on interviews with selected experts, is presented together with the results of the criteria importance ranking based on the Analytic Hierarchy Process (AHP) method. The research presented in this paper is interdisciplinary and brings together tangible and intangible aspects of cultural heritage. The obtained results confirm that rational determination of relative importance of individual criteria for the assessment of architectural heritage can help decision-makers to identify buildings with higher refurbishment priority.
\end{abstract}

KEYWORDS: Multi-criteria decision methods; AHP method; Cultural heritage preservation; Castles

REFERENCE to this paper should be made as follows: Vodopivec, B.; Žarnić, R.; Tamošaitienė, J.; Lazauskas, M.; Šelih, J. 2014. Renovation priority ranking by multi-criteria assessment of architectural heritage: the case of castles, International Journal of Strategic Property Management 18(1): 88-100.

\section{INTRODUCTION}

Monuments have always had a meaning beyond their mere physical and artistic appearance. In the context of the current global developmental challenges, the answer to the economic and value crisis is also sought in cultural roots of a local environment. Historic towns are preserved and given new importance within the new cultural economy (Nyseth, Sognnaes 2013). Therefore, cultural heritage is perhaps more than ever employed as an anchor of identity on a regional level. Due to environmental influences and human factors, cultural heritage is also increasingly under threat; consequently, its preservation is marked by sustainable preventive conservation and regular maintenance. Scientific discourse in the field of heritage conservation introduces holistic integrated approach,

\footnotetext{
* Corresponding author. E-mail: jolanta.tamosaite@vgtu.lt
}

involving stakeholder participation and sustainable strategic planning, which aims to harmonise economic, environmental and social dimensions of the development and integration of humanities and social sciences as well as natural sciences and engineering.

\section{REVIEW OF RENOVATION PRIORITY RANKING BY MULTI-CRITERIA ASSESSMENT OF ARCHITECTURAL HERITAGE BUILDINGS}

Each type of heritage should be investigated in its specific context. Development of appropriate management strategies for monument conservation and maintenance, as well as decisions on priorities for intervention, must therefore be based on reliable data, supported by appropriate documen- 
tation methodology. This need has also emerged within the European project EU-CHIC - European Cultural Heritage Identity Card and research presented in this paper builds upon the results of this project (Žarnić et al. 2012). The aim of the present research is to develop a multi-criteria assessment model for architectural heritage - specifically for castles in Slovenia - that could serve as the basis for informed and scientifically justified determination of reconstruction priorities. The model is designed to propose the allocation of resources for the reconstruction of buildings with the highest total score obtained by the proposed method, or, in other words, to buildings with the highest assigned priority.

Castles in Slovenia were selected as a case study in order to adjust the proposed model to the specific type of heritage. As Slovenia is rich in castle heritage - more than 1300 castles were identified within a relatively small territory, and 90 of them constitute representative sample of preserved buildings (Stopar 2012) - this case study is justifiable. Being an integral part of built environment and landscape, they enable research into various aspects of integrated cultural heritage preservation, such as, for example, environmental protection, regional development and spatial planning (Fairclough et al. 2007). Slovenian castle heritage has been intensively investigated over the past two decades (Sapač 2012). According to Slovenian legislation, the monument owner is obliged to preserve it while respecting the prescribed specific protection regime. Consequently, funds required for preservation and maintenance of immovable heritage are usually greater than costs of maintenance of other types of property. Decisions related to selection of monuments, to which the funds should be allocated, and their priority ranking must, therefore, be scientifically justified, comprehensive and consistent (Drury, McPherson 2008).

The presented research is interdisciplinary and brings together different fields of knowledge in the area of cultural heritage preservation. Development of the method presented in this paper proceeds through the following sequence of consecutive activities:

- Definition of criteria and sub-criteria of the method;

- Determination of the relative importance of the criteria and sub-criteria based on structured interviews with selected experts and the method of Analytic Hierarchy Process (AHP) found by Saaty (1980);

- Critical reflexion upon the obtained results.
Multi-criteria decision-making (MCDM) methods and processes have been widely addressed in scientific literature over the last years. MCDM for heritage assessment presents the area of active research, which receives an increasing attention; however, so far there has been no single generally accepted system for multi-criteria heritage assessment (Fairclough et al. 2007). Definition of the multi-criteria model for the assessment of architectural heritage, which is proposed in this article, arises from the field of assessment of the values of cultural heritage (Price et al. 1996; Battaini-Dragoni 2005) as well as from the principles of integral preservation, which combine tangible and intangible properties of cultural heritage (Appelbaum 2007; Drury, McPherson 2008).

The research devoted to establishment of methodological approach, which combines several different heritage properties or values, is currently related to research fields of decision theory and MCDM (Saaty, Shang 2011). Those methods were first implemented in the areas of environmental protection (Dupagne et al. 2004), cultural landscape (Skoglund, Svensson 2010) and economic evaluation (Verbič, Slabe-Erker 2009).

Moffett and Sarkar (2006) provide an overview of MCDM methods that may potentially be used during systematic conservation planning. Discussing the use of AHP, Saaty and Sagir (2009) address the issue of tangible and intangible properties and the problem of dealing with heterogeneous data or nonhomogeneous elements, where they propose AHP method upgrade with clustering of elements (Saaty, Shang 2011). Table 1 provides more information about AHP method approaches to different ways in evaluation of decision solutions.

It can be summarised that decision-making regarding sustainable cultural heritage preservation is a problem that receives significant attention. Various models and decision-making tools were proposed by researchers working in this field. Establishment of renovation intervention priorities has also been addressed in several articles, mainly related to MCMD and AHP method, however less in the cultural heritage domain, indicating this field of research as a promising and challenging area of further studies.

\section{DEVELOPED MODEL OF ARCHITECTURAL HERITAGE}

\subsection{Importance of criteria and related issues}

Restoration of heritage buildings may last for decades. As such, it should start with a complex in- 
Table 1. The decision approaches using AHP decision method techniques

\begin{tabular}{|c|c|c|}
\hline AHP approaches & Authors & Evaluating the problem field approach \\
\hline \multirow{22}{*}{$\begin{array}{l}\text { Certain decision } \\
\text { approaches }\end{array}$} & Levary (2008) & Ranking foreign suppliers \\
\hline & Girard and De Toro (2007) & Various cultural and natural heritage criteria \\
\hline & Ishizaka et al. (2012) & AHP-based sorting approach \\
\hline & Bhattacharya et al. (2010) & Cost factor measure \\
\hline & Čiegis et al. (2009) & Sustainable development \\
\hline & Chan and Chan (2010) & AHP model for apparel industry \\
\hline & Vidal et al. (2011) & Evaluation of the complexity of projects \\
\hline & Duleba et al. (2012) & Dynamic analysis on the supply of public transport by buses \\
\hline & Kull and Talluri (2008) & Risk reduction model \\
\hline & Reza et al. (2011) & Life cycle analysis \\
\hline & Aghdaie et al. (2012) & Prioritization of construction projects of municipalities \\
\hline & Mafakheri et al. (2011) & Two-stage dynamic programming \\
\hline & Dutta and Husain (2009) & MCDM to built heritage \\
\hline & Ordoobadi (2010) & Taguchi loss function in supply chain \\
\hline & Zavadskas et al. $(2010,2012)$ & Weights determining \\
\hline & Но (2008) & Integrated AHP approach \\
\hline & Ishizaka and Labib (2009) & AHP-based sorting approach \\
\hline & Wang and Zeng (2010) & Selection of historic buildings \\
\hline & Tuan and Navrud (2007) & Choice modelling \\
\hline & Giove et al. (2010) & Multi-criteria decision-making for built heritage \\
\hline & Sivilevičius (2011) & Modelling the interaction of transport system elements \\
\hline & Kim et al. (2010) & Cultural heritage restoration \\
\hline \multirow{7}{*}{$\begin{array}{l}\text { Basic fuzzy hybrid } \\
\text { approaches }\end{array}$} & Sevkli et al. (2010) & AHP weighted fuzzy logic hybridization \\
\hline & Wang and Yang (2009) & Fuzzy compromise programming \\
\hline & Amid et al. (2011) & Weighted max-min fuzzy decision model \\
\hline & Tsai and Hung (2009) & Fuzzy goal programming \\
\hline & Labib (2011) & Fuzzy linguistic expression \\
\hline & Chen and Chao (2012) & Consistent fuzzy preference relations \\
\hline & Chamodrakas et al. (2010) & Fuzzy AHP; Interval valued pairwise comparison \\
\hline \multirow{6}{*}{$\begin{array}{l}\text { Triangular fuzzy } \\
\text { hybrid approaches }\end{array}$} & Chan et al. (2008) & Global supplier selection \\
\hline & Bottani and Rizzi (2008) & AHP-based clustering technique \\
\hline & Yang et al. (2008) & Non-additive fuzzy integral \\
\hline & Lee $(2009 a, b)$ & Benefit, opportunity, cost, and risk model \\
\hline & Kilincci and Onal (2011) & Fuzzy AHP \\
\hline & Punniyamoorthy et al. (2011) & Fuzzy modelling \\
\hline
\end{tabular}

vestigation of buildings as well as entire quarters. This approach ensures an enhanced functionality of reconstructed or new buildings, preservation of their architecture as well as protection of the specific culture heritage buildings structure. Heritage preservation encourages civil engineers working in the fields of sustainable construction and environmental engineering to study the durability of historic structures and materials (concretes, rocks, steels, wood, etc.), which contributes to local economy in the present for the future benefit (Al-Mukhtar 2012). Conservation, restoration and adaptation projects in historic residences are lengthy and expensive, especially in places with extensive dilapidation (Murzyn-Kupisz 2013). The environment of castles in Slovenia is obviously impacted by numerous social interest groups, which somewhat aggravates collection of data required for decision-making. Data collection requires calculations, visual assessment of objects and their environment, as well as in-depth art historical and other humanities and social studies (Žarnić et al. 2012).

Just as any other building, a castle is characterised using structural and artistic features as well as performance; consequently, further use of castles has to be based on their value to the society. Therefore, performance of castles as well as other buildings must be ensured assessing the need for investments and possible results. Plans to construct a new building involve considerations of various needs of clients, the public and environment, which may be projected in advance.

Preparation for restoration of castles or other heritage buildings or their adaptation to needs of contemporary groups of the society is inevitably 
related to a greater number of obstacles than construction of new buildings or renovation of residential buildings. Therefore, the need emerges to prognosticate the most important indicators that could allow assessing further rational use of castles. Once the most important criteria are set to determine options of the further use of castles, primary data on success of failure of a project may be determined.

\subsection{Definition of elements of multi-criteria assessment of architectural heritage}

Today, various methods and models are used in construction and real estate and its separate segments worldwide (Kaklauskas et al. 2011). The demonstrated development of the multi-criteria method is based on the key aspect - the definition of criteria (that cover material and non-material aspects of preservation) and determination of their mutual relative importance. Within this process, the criteria must be clearly defined and quantified in advance. Only then, facilities that are the most eligible for renovation in terms of their importance and the state of conservation can be identified in an objective manner. In general, the conservation of historic environments requires maintaining a balance between preserving the past for its intrinsic value and accommodating new demands (Cho, Shin 2014; Zan, Baraldi 2013). Objectification of decision-making with the hierarchical classification of criteria, performed on the basis of their mutual relative importance, which is necessary due to the potential subjectivity of judgements (Dutta, Husain 2009), contributes to the transparency and comprehensibility of the approach and simplifies aspects of individual disciplines. The proposed quantitative method may be helpful in deciding on intervention priorities; however, to identify the significance of heritage as a basis for monument proclamation act, for example, should still derive from the evaluation process of individual disciplines involved in the preservation of cultural heritage.

Criteria of the proposed method were defined on the following contextual bases:

- Detailed knowledge of the research object (preservation of architectural heritage, castles);

- Detailed knowledge of the history and theory of conservation;

- Detailed knowledge of the Slovenian spatial and contextual specificities.

Those substantive bases determine criteria of the proposed method as:
- Multidisciplinary;

- Descriptive (importance: non-material properties) and measurable (state of conservation: material properties);

- Globally and locally defined according to the context and location;

- Universal and specific according to the type of heritage.

Criteria definition was carried out in five consecutive steps:

1. Critical analysis of literature: identification of values and determination of frequency of mention;

2. Comparative analysis of Slovenian and European literature;

3. Aggregation of semantically related values;

4. Definition of criteria based on values;

5. Criteria tree modelling.

In the first part of the research, which is presented in this article, the word "value" was used as a general term indicating various heritage properties, which are mentioned in the analysed material, such as value, importance and significance. Later on, criteria were defined on the basis of identified values, and terms criteria and sub-criteria were used for elements, according to which individual buildings were assessed.

Critical content analysis covered the key material of architectural heritage conservation (Jokilehto 2005) and related field of value assessment. As a result, a list of 53 different values, designating the importance of heritage, was compiled. Frequency of each individual value recorded in the survey was added to the list (Vodopivec 2012). During the second step, a comparison between the lists of the first ten most frequently mentioned values in international and Slovenian materials was carried out. The comparison demonstrated a very high correlation between the two lists (Vodopivec 2012).

The research conducted during the third step focused on the aggregation of previously identified semantically related values. Frequency of records of the value under consideration was added to the aggregated value. The result of the third step is a list of 31 values and the frequency of their records in the literature survey. Five elements were mentioned only once in the analysed materials. Therefore, they were considered as unimportant and consequently not taken into the account in further analysis. The number of records in the literature for the 26 most frequently mentioned values is presented in Fig. 1. Analysis of the surveyed literature (that can be considered as the key material) thus indicates that the historical, economic and cultural 
values of immovable heritage are strongly emphasised in comparison with other listed values.

During the fourth step, values were translated into criteria and, during the next phase of the research, were classified into the criteria tree according to their meaning. Criteria tree design, carried out during the fifth step, followed the results of the previous four steps, aforementioned contextual basis and recommendations for efficient and consistent use of the AHP method (Expert 2004; Ishizaka, Labib 2009). First, the principal criteria were set. Based on the definition of sustainable development that needs to be accounted for in contemporary society, economic, environmental and social significance were added to the principal criteria (Mebratu 1998). Further, three most frequently mentioned criteria from the conducted analyses were added: historic, aesthetic and cultural significance (Vodopivec 2012). Conservation status and risks were identified as the principal criteria as well (Žarnić et al. 2012).

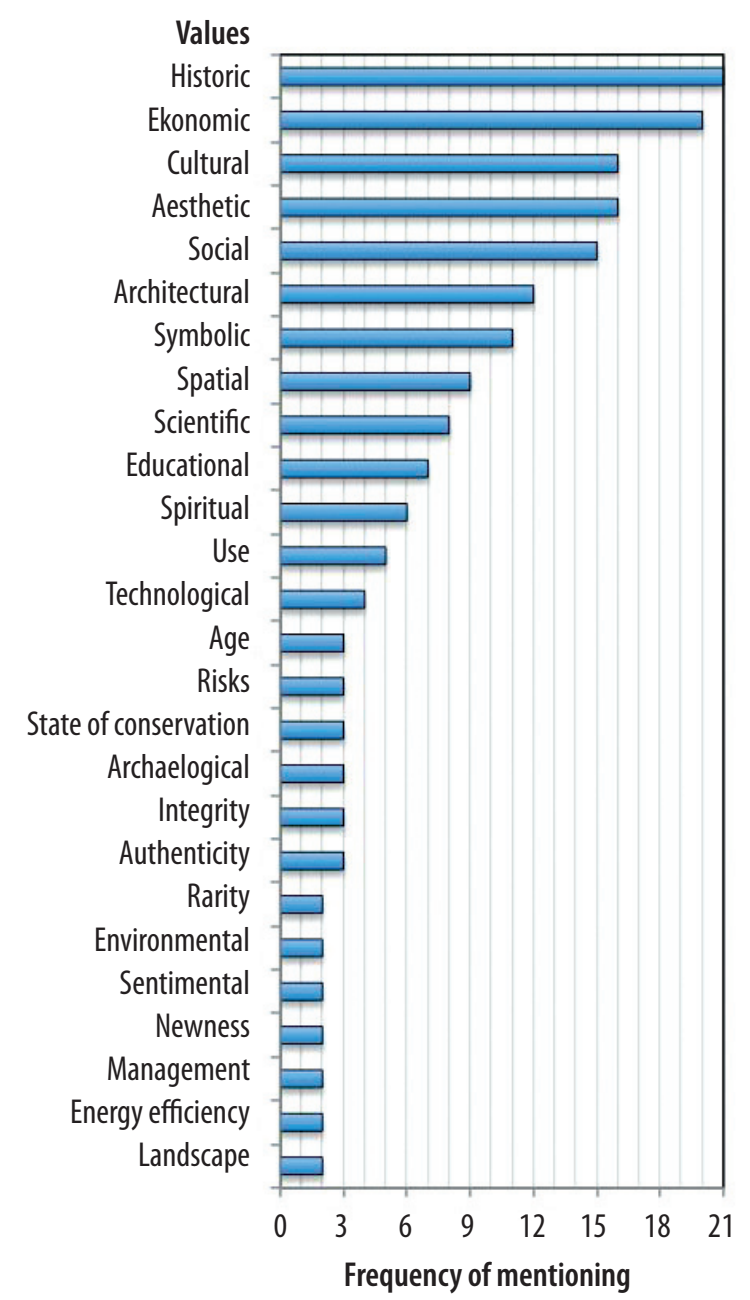

Fig. 1. Graphical presentation of frequency of records for each individual value, identified on the basis of extensive conservation literature analysis
Next, value assessment theory leads to merger between the symbolic significance and cultural significance (Fairclough et al. 2007). During the next step, three sub-criteria were attributed to each of eight principal criteria according to their meaning. Consequently, the remaining 18 criteria were classified as sub-criteria of historic, aesthetic, social, cultural-symbolic and environmental significance. State of conservation, risks and economic significance were further defined on the basis of the critical content analysis of the relevant literature. The final result of the fifth step is the two-layered criteria tree with eight principal criteria, each of them with three sub-criteria, as illustrated in Fig. 2.

\subsection{Determination of relative importance of criteria and sub-criteria of analysed problem}

Once the problem was structured into the criteria tree as a result of the aforementioned five methodological steps, the research took advantage of intelligent technology (Saaty, Sagir 2012). Values or weights of criteria and sub-criteria reflecting

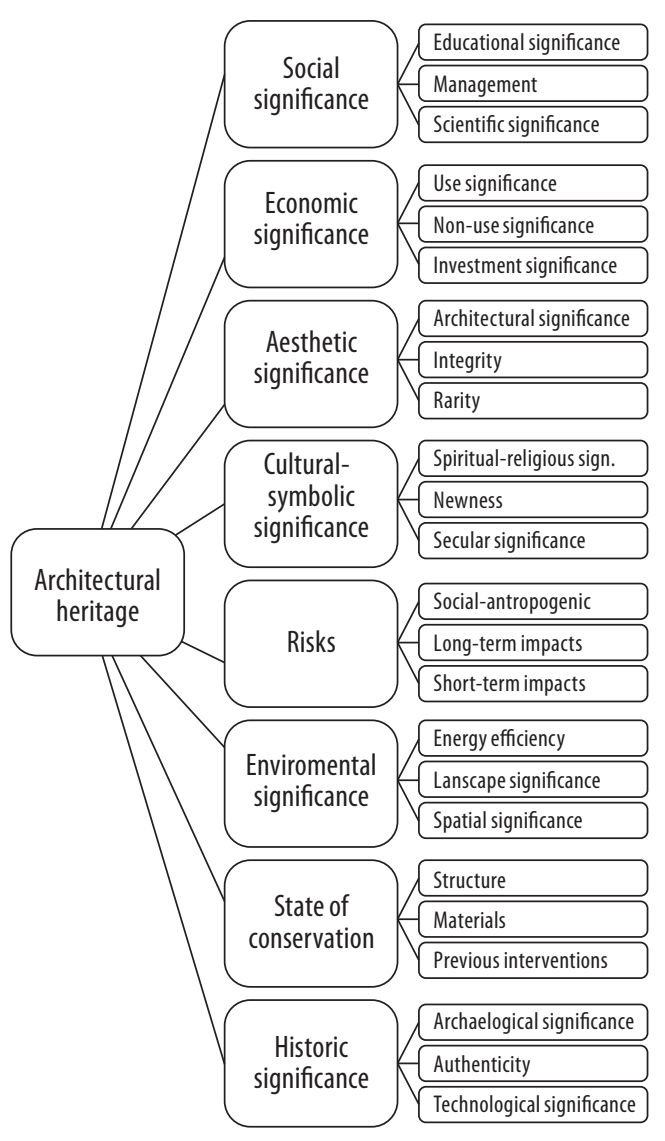

Fig. 2. Two-layered criteria tree with eight criteria, each with three sub-criteria, proposed for architectural heritage refurbishment priority identification 
their relative importance were determined by the AHP method on the basis of structured interviews with selected experts. Computer software Expert Choice was used for this purpose (Expert 2004). This AHP method-based tool for scientifically established multi-criteria decision-making takes into account relative subjectivity of judgments as well as empirical data. The software enables transparent structuring of the problem and assesses the importance of various criteria by pairwise comparisons. Criteria can be compared by using one of the three evaluation scales: descriptive, numerical and graphical. Once the relative importance of criteria is determined, the total criteria values and the ranking order of criteria or alternatives can be defined in order to support a decision maker in selecting the optimal solution. The software continuously evaluates relationships between answers given by respondents and determines logical inconsistency of judgments, which enables detection of potential errors in judgments or their actual inconsistency. Inconsistencies lower than 0.1 are considered acceptable (Expert 2004).

The tree of criteria and sub-criteria was designed by using the above-mentioned software. The tree forms the basis of the model for multicriteria assessment of castles. The starting point of the empirical part of the research was determination of the set of castles in need of renovation and with limited available funds. Therefore, priority of renovations needs to be determined based on a set of given criteria. It is important to emphasise that proclaimed monuments with already recognised importance were assessed, and that the assessment is carried out for the existing state of conservation. Descriptive five-step evaluation scale was employed. Determination of the mutual relative importance of criteria and sub-criteria was carried out using pairwise comparisons of first of each main criterion with the rest, and then of three subcriteria defining each main criterion.

\subsection{Presentation of the sample of selected experts and the course of the analysis}

Participation of informed experts has proven to be a reliable way to test and verify problem structure consistency and applicability (Saaty, Shih 2009; Kutut et al. 2014). For this purpose experts, who were able to provide reliable judgements, were chosen with special emphasis on their:

- Professional background and education;

- Experience (at least five years in the cultural heritage preservation field);

- Professional integrity.
The sample of respondents/experts was selected with the help of assigning at least one and maximum two disciplines to each of the eight main criteria. Next, experts were determined for each identified discipline by using the above criteria. Consequently, the research involved 17 experts from 12 disciplines (Table 2), of which the majority had a background in social sciences and humanities. Disciplines were defined on the basis of the Common European Research Classification Scheme, annex to CERIF (Common European Research project Information Format, Official Journal of the European Communities, L189, 1991), Act on Professional and Academic Scientific Titles (1998) and Regulation on the self-employed in the field of culture (2004, 2006 and 2009). All invited experts agreed to the interview.

Experts defined their fields of work on the presentation form, which was completed during the interview of each respondent. The sample covered 10 fields of work related to the preservation of cultural heritage (Table 3). The figures represent the number of experts in the particular field of work. Some experts with interdisciplinary background are listed in a number of respective fields.

Structured interviews based on AHP method were carried out. Experts evaluated criteria with the help of software Expert Choice and on the basis of criteria tree (Fig. 2). Detailed description of each criteria and subcriteria was provided in written form and was given to each expert during the interview (Vodopivec 2012).

At the end of the interview, experts were given an opportunity to provide their observations and comments as regards the proposed model. The quantitative part of the evaluation, for each expert, results in the form of a pairwise comparisons matrix:

$$
A=\left(a_{i j}\right)=\left[\begin{array}{cccc}
1 & \frac{w_{1}}{w_{2}} & \cdots & \frac{w_{1}}{w_{m}} \\
\frac{w_{2}}{w_{1}} & 1 & \cdots & \frac{w_{2}}{w_{m}} \\
\vdots & \vdots & \ddots & \vdots \\
\frac{w_{m}}{w_{1}} & \frac{w_{m}}{w_{2}} & \cdots & 1
\end{array}\right],
$$

where: $a_{i j}$ - relative importance of criterion $i$ compared, to criterion $j ; a_{j i}$ - relative importance of criterion $j$ compared to criterion $i$. 
Group decision making involves aggregation of diverse individual preferences to obtain a single collective preference. All representatives of the all groups assessed the stated criteria was established according to the Saaty scale. Respondents new to the calculation methodology of AHP method were introduced to data inputting principles and criteria assessment methodology. Relative importance of criteria were obtained by averaging the individual assessments of interviewed experts. The largest relative differences are perceived for Risk and State of conservation; the obtained values show that risks are judged to be more important than cultural-symbolic significance by a criterion of 2,40 , while state of conservation is judged to be more important than historic, and cultural-symbolic significance, by a criterion of 2,56 and 2,78, respectively.

Table 2. Disciplines, represented in the sample of experts collaborating in the AHP analysis

\begin{tabular}{ll}
\hline Discipline & $\begin{array}{l}\text { Number of } \\
\text { respondents }\end{array}$ \\
\hline Spatial planning & 1 \\
Archaeology & 1 \\
History & 1 \\
Art history & 1 \\
Sociology & 2 \\
Architecture & 1 \\
Administrative sciences & 1 \\
Ethnology & 1 \\
Economy & 2 \\
Civil Engineering & 4 \\
Geology & 1 \\
Protection and restoration of art work & 1 \\
\hline
\end{tabular}

Table 3. Fields of work, covered by the sample of experts who participated in the AHP analysis

\begin{tabular}{ll}
\hline Field of work & $\begin{array}{l}\text { Number of } \\
\text { respondents }\end{array}$ \\
\hline Theory of conservation & 3 \\
Restoration & 2 \\
Conservation & 3 \\
Theory of cultural heritage materials & 4 \\
Theory of cultural heritage structures & 3 \\
Rehabilitation planning and implemen- & 3 \\
tation & 5 \\
Cultural heritage management & 1 \\
Spatial planning & 11 \\
Knowledge creation & 13 \\
Knowledge transfer & 1 \\
Administrative sciences & 1 \\
Ethnology & 2 \\
Economy & 4 \\
Civil Engineering & 1 \\
Geology & 1 \\
Protection and restoration of art work & \\
\hline
\end{tabular}

\section{CASE STUDY: RENOVATION PRIORITY RANKING BY MULTI-CRITERIA ASSESSMENT OF CASTLES}

Castle buildings are among the most distinctive elements of Slovenian build environment and cultural landscape. Medieval castles emerged in the Romanesque period (second half of the $11^{\text {th }}$ till the middle of the $13^{\text {th }}$ century) and in the Gothic period (middle of the $13^{\text {th }}$ century till the middle of the $15^{\text {th }}$ century). In the $17^{\text {th }}$ and $18^{\text {th }}$ century they were rebuild, because many of them were damaged mostly due to the previous peasants revolts and Turkish invasions, and in the $19^{\text {th }}$ century romantic reconstructions took place. Medieval castles on the Slovenian territory had strong defence function as the borderline of the Holy Roman Empire, as well as they were centres of the feudal social order (Sapač 2012; Stopar 2012). Slovenian Register of Cultural Heritage contains 29,338 units of heritage; $70 \%$ represent built heritage. There are 451 castles objects' entries, of which 166 objects under the typological category castle (source of data: Register of immovable cultural heritage - Rkd, Ministry of Culture of the Republic of Slovenia, retrieved on 29. 3. 2012).

Once the mutual importance of criteria and sub-criteria was determined by AHP method. The normalized values, or eigenvectors, for the level of criteria tree (Fig. 2) are calculated as:

$$
w_{i}^{\left(L_{1}\right)}=\frac{\left(\sqrt[N]{\prod_{j=1}^{N} a_{i j}}\right)}{S_{L_{1}}},
$$

where: $a_{i j}$ - first level relative importance of criterion $i$ compared to criterion $j ; w_{i}^{\left(L_{1}\right)}-$ first level of criteria tree, $i=1, \ldots, N, S_{L_{1}}$ - the value of the elements of each $i$-th row of first level matrix; in the formula $N=1, \ldots, n$ and

$$
S_{L_{1}}=\sum_{j=1}^{N} w_{j}^{\left(L_{1}\right)},
$$

where: $w_{j}^{\left(L_{1}\right)}$ - the value of each $j$-th row elements, in the formula $j=1, \ldots, N$,

Analogy expressions are valid on the second level of criteria tree $w_{k}^{\left(L_{2}\right)}$ :

$$
w_{k}^{\left(L_{2}\right)}=\frac{\left(\sqrt[M]{\prod_{k=1}^{M} b_{k j}}\right)}{S_{L_{2}}},
$$

where: $w_{k}^{\left(L_{2}\right)}$ - second level of criteria tree, in the formula $k=1, \ldots, M ; b_{k j}$ - second level relative importance of criterion $k$ compared to criterion $j$ and 


$$
S_{L_{2}}=\sum_{k=1}^{M} w_{k}^{2}
$$

where: $S_{L_{2}}$ - the value of the elements of each $k$-th row of second level matrix, $k=1, \ldots, M$.

In the presented practical example $N=8$ and $M=3$.

Calculation sequence and results of eigenvector are presented in Table 4. Average of assessments given by all representatives is used for calculations applying the AHP method (Table 5) (Sivilevičius 2011).

Each of the column elements obtained is divided by the respective weight $w_{i}^{\left({ }^{(} i\right)}$. If matrix $\mathbf{A}$ is ideally consistent, the relationships between all the elements will be the same. They will be equal to the largest eigenvalue $\lambda_{\max }$ being sought (Table 5). If the relationships differ (which is usually the case in real calculation), the average relationship is taken as the largest eigenvalue $\lambda_{\text {max }}$.

Relative importance and ranking order of criteria and sub-criteria were then calculated. Results presented in Table 6 indicate that criteria risks and state of conservation account for almost 40\% of the overall relative importance, which means that both criteria significantly affect the overall assessment of a certain architectural heritage object. Analysis of importance of each individual sub-criterion (Table 6) shows that sub-criteria were valued rather equally. The consistency ratio $(C R)$ of the matrix and overall inconsistency for the hierarchy are calculated in order to control the results of this method.

The Consistency Ratio $(C R)$ is used to make direct estimation of the consistency of pairwise comparisons.

First step is to analyse the consistency of each comparison matrix by calculating the consistency index $(C I)$ and the second step is to calculate the consistency ratio $(C R)$ :

$$
\begin{aligned}
C R^{\left(L_{i}\right)} & =\frac{C I^{\left(L_{i}\right)}}{R I}, \\
C I^{\left(L_{i}\right)} & =\frac{\lambda_{\text {max }, i}^{\left(L_{i}\right)}-n}{n-1} .
\end{aligned}
$$

According to the solution, it could be stated that where $R I$ is a random index, which is shown in Table 6 , and $n$ is matrix size.

The value of consistency ratio $C R$ - that is smaller than or equal to 0.1 - is acceptable, implying that the matrix is consistent (Table 6). Criteria priorities are as follow: $X_{6} \succ X_{2} \succ X_{4} \succ X_{5} \succ X_{3} \succ X_{7} \succ X_{1} \succ X_{8}$.
All invited experts responded positively to the invitation and agreed to be interviewed, which implies that the multi-criteria assessment topic is recognised as important and relevant in the field of conservation theory and practice. With certain comments, summarised below, experts were in favour of the proposed methodology. Structure of the proposed model that allows assessment of each heritage type and object in its specific context, defined by various factors represented by criteria and sub-criteria, was particularly pointed out as a distinctive advantage of the approach.

During the interviews, special attention was devoted to verification of the cases where inconsistency of the judgements was observed. Experts who recorded inconsistency of judgments within acceptable levels, and those who recorded inconsistency of judgments higher than 0.1 (four had a level higher than 0.1 , of which the highest rate was 1.3), at the end of the survey and after a short clarification of calculated values, confirmed that the final ranking of criteria reflects their opinions and preferences. Experts from natural and technical sciences generally evaluated criteria within larger range, using also marks "very strong" and "extreme", whilst estimations by social sciences and humanities experts generally fluctuated between marks "equal" and "moderate". This may partly explain the high priority range of criteria risks and state of conservation over the other criteria, even though the proportion of technical experts in the sample was smaller. Moreover, dominance of two technical criteria over the others, mainly from social sciences and humanities, suggests that field of work (i.e. working experience) has larger impact on the judgements of experts than their basic educational background. This is especially true for experts, art historians or sociologists, for example that are working with objects in-situ as conservators. They gave priority to the preservation of material substance over interpretation and presentation of other values. However, it can be anticipated that relative importance of criteria is context-sensitive and would be defined differently, if other type of heritage, such as artistic objects, for example, was assessed by a different group of experts.

Since the final goal of the research was to obtain commonly agreed relative importance of the criteria and sub-criteria for the evaluation of the built heritage, the comments of respondents were examined with due attention. It was observed that they were predominantly focused on methodology and structure of the criteria tree. At first, conservators and restorers opposed to ranking of criteria, 
Table 4. Calculation sequence and results of eigenvector $w_{i}^{\left(L_{1}\right)}$ of first level

\begin{tabular}{|c|c|c|c|c|c|c|c|c|}
\hline \multirow[t]{2}{*}{ Calculating step } & \multicolumn{8}{|c|}{ Criteria number } \\
\hline & $x_{1}$ & $x_{2}$ & $x_{3}$ & $x_{4}$ & $x_{5}$ & $x_{6}$ & $x_{7}$ & $x_{8}$ \\
\hline Step I & $w_{1}$ & $w_{2}{ }_{2}$ & $w_{3}$ & $w_{4}$ & $w_{5}$ & $w{ }_{6}$ & $w_{7}$ & $w_{8}$ \\
\hline $\begin{array}{l}\text { Calculated elements } a_{i j} \text { from each row of } \\
\text { Fig. 3. e.g., first row } a_{i j} \text { elements multipli- } \\
\text { cation. }\end{array}$ & \multicolumn{8}{|c|}{$w_{i}^{\prime \prime\left(L_{1}\right)}=\prod_{j=1}^{8} a_{i j}$} \\
\hline Each row multiplication & 76.538 & 58.297 & 0.883 & 0.792 & 0.437 & 0.0193 & 0.096 & 0.396 \\
\hline Step II & $w_{1}^{\prime}$ & $w_{2}^{\prime}$ & $w_{3}^{\prime}$ & $w_{4}^{\prime}$ & $w_{5}^{\prime}$ & $w_{6}^{\prime}$ & $w_{7}^{\prime}$ & $w_{8}^{\prime}$ \\
\hline $\begin{array}{l}\mathrm{N} \text { degree root is calculated from each row } \\
\text { calculated } w_{i}^{\prime\left(L_{1}\right)} \text {. E.g., from obtained row } \\
\text { second element } 8 \text { th degree root. }\end{array}$ & \multicolumn{8}{|c|}{$w_{i}^{\prime\left(L_{1}\right)}=\sqrt[8]{\omega_{i}^{\prime \prime\left(L_{1}\right)}}=\sqrt[8]{\prod_{j=1}^{8} a_{i j}}$} \\
\hline $\begin{array}{l}\text { Root of all criteria multiplications } a_{i j} 8 \text { th } \\
\text { degree }\end{array}$ & 1.719 & 1.662 & 0.985 & 0.971 & 0.902 & 0.814 & 0.747 & 0.668 \\
\hline Step III & $w_{1}^{(\mathrm{L} 1)}$ & $w_{2}^{(\mathrm{L} 1)}$ & $w_{3}^{(\mathrm{L} 1)}$ & $w_{4}^{(\mathrm{L} 1)}$ & $w_{5}^{(\mathrm{L} 1)}$ & $w_{6}^{(\mathrm{L} 1)}$ & $w_{7}^{(\mathrm{L} 1)}$ & $w_{8}^{(\mathrm{L} 1)}$ \\
\hline $\begin{array}{l}\text { Each element } w_{i}{ }^{\prime\left(L_{1}\right)} \text { is divided by the sum } \\
\text { of all elements }\end{array}$ & \multicolumn{8}{|c|}{$w_{i}^{\left(L_{1}\right)}=\frac{\sqrt[8]{\prod_{j=1}^{8} a_{i j}}}{\sum_{i=1}^{8} \sqrt[8]{\prod_{j=1}^{8} a_{i j}}}$} \\
\hline $\begin{array}{l}\text { All criteria elements normalized } w_{i}^{\left(L_{1}\right)} \text { val- } \\
\text { ues (eigenvector) }\end{array}$ & 0.088 & 0.198 & 0.104 & 0.115 & 0.112 & 0.204 & 0.100 & 0.079 \\
\hline
\end{tabular}

Table 5. Consistency of the matrix and agreement between expert opinions

\begin{tabular}{|c|c|c|c|c|c|c|c|c|}
\hline \multirow[t]{2}{*}{ Calculation step } & \multicolumn{8}{|c|}{ Criteria number } \\
\hline & $x_{1}$ & $x_{2}$ & $x_{3}$ & $x_{4}$ & $x_{5}$ & $x_{6}$ & $x_{7}$ & $x_{8}$ \\
\hline Step I & $\lambda^{(L 1)^{\prime}} \max .1$ & $\lambda^{(L 1)^{\prime}} \max .2$ & $\lambda^{(L 1)^{\prime}} \max .3$ & $\lambda^{(L 1)^{\prime}} \max .4$ & $\lambda^{(L 1)^{\prime}} \max .5$ & $\lambda^{(L 1)^{\prime}} \max .6$ & $\lambda^{(L 1)^{\prime}} \max .7$ & $\lambda^{(L 1)^{\prime}} \max .8$ \\
\hline $\begin{array}{l}\text { Calculated values of the high- } \\
\text { est eigenvalue } \lambda_{\max }{ }^{(L 1)} \text { compo- } \\
\text { nents }\end{array}$ & $\lambda_{\text {max }, i}^{\left(L_{1}\right)}{ }^{\prime}=$ & $\frac{a_{i j} w_{j}^{\left(L_{1}\right)}}{w_{i}^{\left(L_{1}\right)}}$ & $\sum_{\substack{\lambda_{\text {max }, i}^{\left(L_{1}\right)} \\
\underbrace{8}_{j=1}}}^{8}$ & $\frac{\lambda_{1}^{\left(L_{1}\right)},}{8}$ & & & & \\
\hline $\begin{array}{l}\text { The element of the column by } \\
\text { the respective weight } w_{i}^{(L 1)} \\
\text { and the eigenvalue by each } \\
\text { expert }\end{array}$ & 8.173 & 8.227 & 8.042 & 8.143 & 8.019 & 8.093 & 8.168 & 8.041 \\
\hline \multicolumn{9}{|l|}{ Step II } \\
\hline \multicolumn{9}{|l|}{ Consistency ratio of the matrix } \\
\hline & $C R^{\left(L_{1}\right)}=$ & $\frac{I_{1}^{\left(L_{1}\right)}}{R I}=\frac{\frac{\substack{\lambda_{\max , i}^{\left(L_{1}\right)} \\
n}}{1 .}}{R I}$ & $\frac{{ }_{\mathrm{s}, i}-n}{-1}=\frac{\lambda_{\mathrm{m}}^{(1}}{41}$ & $\frac{\left.L_{1}\right)-8}{\frac{\left.L_{1}\right)}{2-1}}$ & & & & \\
\hline $\begin{array}{ll}\text { The values of a ran- } & \text { Matrix } \\
\text { dom consistency } & \text { order }(n)\end{array}$ & 3 & 4 & 5 & 6 & 7 & 8 & 9 & 10 \\
\hline Random index $\quad R I$ & 0.58 & 0.90 & 1.12 & 1.24 & 1.32 & 1.41 & 1.45 & 1.49 \\
\hline Consistency ratio $\quad C R^{(L 1)}$ & $\begin{array}{l}C R^{(L 1)}= \\
0.011\end{array}$ & & & & & & & \\
\hline
\end{tabular}

The value are smaller than 0.1. i.e. the matrix is consistent and expert estimates are in agreement. 
Table 6. The relative importance of the criteria and sub-criteria weights by applying AHP method

\begin{tabular}{|c|c|c|c|c|c|}
\hline $\begin{array}{l}\text { Criteria } \\
\text { symbol }\end{array}$ & $\begin{array}{l}\text { Significance of } \\
\text { criteria type }\end{array}$ & $\begin{array}{l}\text { Calculated criteria } \\
\text { weights } w_{i}^{(L 1)}\end{array}$ & Sub-criteria & $\begin{array}{l}\text { Sub-criteria } \\
\text { weights } w_{K}^{(L 2)}\end{array}$ & $\sum_{k=1}^{M} b_{k j}=1$ \\
\hline \multirow[t]{3}{*}{$X_{1}$} & \multirow{3}{*}{$\begin{array}{l}\text { Economic } \\
\text { significance }\end{array}$} & \multirow[t]{3}{*}{0.088} & Use value & 0.221 & \multirow[t]{3}{*}{1.00} \\
\hline & & & Investment significance & 0.380 & \\
\hline & & & Non-use value & 0.399 & \\
\hline \multirow[t]{3}{*}{$X_{2}$} & \multirow{3}{*}{$\begin{array}{l}\text { State of } \\
\text { conservation }\end{array}$} & \multirow[t]{3}{*}{0.198} & Previous interventions & 0.198 & \multirow[t]{3}{*}{1.00} \\
\hline & & & Structure & 0.382 & \\
\hline & & & Materials & 0.420 & \\
\hline \multirow[t]{3}{*}{$X_{3}$} & \multirow{3}{*}{$\begin{array}{l}\text { Environmental } \\
\text { significance }\end{array}$} & \multirow[t]{3}{*}{0.104} & Energy efficiency & 0.165 & \multirow[t]{3}{*}{1.00} \\
\hline & & & Spatial significance & 0.356 & \\
\hline & & & Landscape significance & 0.479 & \\
\hline \multirow{3}{*}{$X_{4}$} & \multirow{3}{*}{$\begin{array}{l}\text { Historic } \\
\text { significance }\end{array}$} & \multirow[t]{3}{*}{0.115} & Archaeological significance & 0.219 & \multirow[t]{3}{*}{1.00} \\
\hline & & & Technological significance & 0.233 & \\
\hline & & & Authenticity & 0.549 & \\
\hline \multirow[t]{3}{*}{$X_{5}$} & \multirow{3}{*}{$\begin{array}{l}\text { Social } \\
\text { significance }\end{array}$} & \multirow[t]{3}{*}{0.112} & Management & 0.274 & \multirow[t]{3}{*}{1.00} \\
\hline & & & Educational significance & 0.324 & \\
\hline & & & Scientific significance & 0.402 & \\
\hline \multirow[t]{3}{*}{$X_{6}$} & \multirow[t]{3}{*}{ Risk } & \multirow[t]{3}{*}{0.204} & Social-anthropogenic & 0.274 & \multirow[t]{3}{*}{1.00} \\
\hline & & & Short-term impacts & 0.355 & \\
\hline & & & Long-term impacts & 0.371 & \\
\hline \multirow[t]{3}{*}{$X_{7}$} & \multirow{3}{*}{$\begin{array}{l}\text { Aesthetic } \\
\text { significance }\end{array}$} & \multirow[t]{3}{*}{0.100} & Architectural significance & 0.329 & \multirow[t]{3}{*}{1.00} \\
\hline & & & Integrity & 0.335 & \\
\hline & & & Rarity & 0.336 & \\
\hline \multirow[t]{3}{*}{$X_{8}$} & \multirow{3}{*}{$\begin{array}{l}\text { Cultural- } \\
\text { symbolic } \\
\text { significance }\end{array}$} & \multirow[t]{3}{*}{0.079} & Newness & 0.292 & \multirow[t]{3}{*}{1.00} \\
\hline & & & Spiritual-religious significance & 0.306 & \\
\hline & & & Secular significance & 0.402 & \\
\hline
\end{tabular}

which, as they put it, should all be ranked equally according to their conservation ethics. They only ranked the criteria hierarchically when they derived their judgements form the background of their basic discipline, such as history, architecture and etc. Some experts suggested a different structure of the criteria tree as criteria and sub-criteria seemed misbalanced. The majority of comments concerned semantic overlapping of descriptive criteria, social and cultural-symbolic significances in particular. Some experts also thought that certain aspects should have been exposed at least as a subcriteria; identity, for example, which was placed under social significance in the proposed model. Economic significance was redefined as a quantitative criterion, expressed in terms of price, whilst indirect economic impacts (increased tourist visit of the area, for example) was assigned to the social significance description. Several comments were related to the energy efficiency criteria, which, according to some experts, is difficult to apply in case of castle heritage. Some experts pointed out that certain criterion can prevail over all other criteria. For example, if a building is exposed to numerous risks and is highly structurally vulnerable (risks criterion), it does not fulfil the safety requirements and can therefore directly endanger human health and life, which can actually overrule all other criteria under certain circumstances. To address all this comments, it can be pointed out that the resulting criteria tree is a proposal and the first step to test the response of selected experts. Systematic research approach employed is judged to be sufficiently rigorous for the initial phase.

Comments from respondents suggest that research work in defining elements of multi-criteria method for assessment of architectural heritage should be continued. In line with the proposals of respondents, the following steps of the research are to provide critical re-analysis of the proposed criteria tree, to expand sample of experts into an international arena, and, finally, to test and verify applicability of the model in selected cases of castle heritage in Slovenia as well as in other countries. 


\section{CONCLUSIONS}

Methodology for the development of multi-criteria method for assessment of castles in Slovenia is proposed in this work on the basis of interdisciplinary research work.

Tangible and intangible aspects of cultural heritage preservation are combined, which allows the method to be used also for other types of heritage. In such case, the criteria structure needs to be reconsidered and re-assessed prior to its use. Further, the user needs to be aware of the limitations of the method, in particular the potential simplification of individual scientific disciplines that need to be addressed in the method.

The obtained results confirm the effectiveness of the AHP method in defining the ranking order of criteria according to their importance. The need for precise and clear prior definition of criteria and sub-criteria was clearly demonstrated. Results of interviews with selected experts require further work on the development of methods, confirm the need for such method in Slovenia, indicate potential effective use of the method in practice and confirm the necessity of verification and validation of the method for selected cases of castle heritage in Slovenia. The proposed method is a quantitative tool, results of which should be comprehensively and critically evaluated before the proposed alternative is effectively selected. The overall results of the presented research confirm that multi-criteria method for assessment of architectural heritage can be a relevant and scientifically sound support for decision makers aiming to determine priorities of architectural heritage refurbishment.

The heritage buildings addressed in this paper are those having unique architectural and artistic character. The presented methodology is not applicable only to castles located in cultural landscape but also to those that are forming an integral part of historic urban nuclei. Therefore, we aim to generalize the methodology in order to be used for priority assessment of decisions related to preservation, restoration and use of heritage buildings in general.

\section{ACKNOWLEDGEMENTS}

The authors gratefully acknowledge the cooperation of the experts who participated in the survey, and whose comments contributed significantly to further development of the multi-criteria method of architectural heritage assessment. Valuable ad- vice by Dr. Aleksander Srdić on the use of software Expert Choice is appreciated.

Research presented in this paper was partially funded through a fellowship scheme jointly financed by the European Social Fund and Ministry of Education, Science and Sport of the Republic of Slovenia.

\section{REFERENCES}

Aghdaie, M. H.; Hashemkhani Zolfani, S. H.; Zavadskas, E. K. 2012. Prioritizing constructing projects of municipalities based on AHP and COPRAS-G: a case study about footbridges in Iran, Baltic Journal of Road and Bridge Engineering 7(2): 145-153. http:/l dx.doi.org/10.3846/bjrbe.2012.20

Al-Mukhtar, M. 2012. Editorial: built heritage, European Journal of Environmental and Civil Engineering 16(5): 525-526. http://dx.doi.org/10.1080/19648189.2 012.688531

Amid, A.; Ghodsypour, S. H.; O’Brien, C. 2011. A weighted max-min model for fuzzy multi-objective supplier selection in a supply chain, International Journal of Production Economics 131(1): 139-145. http://dx.doi. org/10.1016/j.ijpe.2010.04.044

Appelbaum, B. 2007. Conservation treatment methodology. Amsterdam: Elsevier.

Battaini-Dragoni, G. 2005. Guidance on heritage assessment "Our cultural diversity is what unites us", Technical Co-operation and Consultancy Programme. Strasbourg: Council of Europe Publishing.

Bhattacharya, A.; Geraghty, J.; Young, P. 2010. Supplier selection paradigm: an integrated hierarchical QFD methodology under multiple-criteria environment, Applied Soft Computing 10(4): 1013-1027. http:// dx.doi.org/10.1016/j.asoc.2010.05.025

Bottani, E.; Rizzi, A. 2008. An adapted multi-criteria approach to suppliers and products selection-an application oriented to lead-time reduction, International Journal of Production Economics 111(2): 763-781. http://dx.doi.org/10.1016/j.ijpe.2007.03.012

Chamodrakas, I.; Batis, D.; Martakos, D. 2010. Supplier selection in electronic marketplaces using satisficing and fuzzy AHP, Expert Systems with Applications 37(1): 490-498. http://dx.doi.org/10.1016/j. eswa.2009.05.043

Chan, F. T. S.; Chan, H. K. 2010. An AHP model for selection of suppliers in the fast changing fashion market, International Journal of Advanced Manufacturing Technology 51(9-12): 1195-1207. http://dx.doi. org/10.1007/s00170-010-2683-6

Chan, F. T. S.; Kumar, N.; Tiwari, M. K.; Lau, H. C. W.; Choy, K. L. 2008. Global supplier selection: a fuzzyAHP approach, International Journal of Production Research 46(14): 3825-3857. http://dx.doi. org/10.1080/00207540600787200

Chen, Y.; Chao, R. 2012. Supplier selection using consistent fuzzy preference relations, Expert Systems with Applications 39(3): 3233-3240. http://dx.doi. org/10.1016/j.eswa.2011.09.010 
Cho, M.; Shin, S. 2014. Conservation or economization? Industrial heritage conservation in Incheon, Korea, Habitat International 41: 69-76. http://dx.doi. org/10.1016/j.habitatint.2013.06.011

Čiegis, R.; Ramanauskiene, J.; Startiene, G. 2009. Theoretical reasoning of the use of indicators and indices for sustainable development assessment, Inzinerine Ekonomika - Engineering Economics (3): 33-40.

Drury, P.; McPherson, A. 2008. Conservation principles, policies and guidance for sustainable management of the historic environment. London: English Heritage.

Duleba, S.; Mishina, T.; Shimazaki, Y. 2012. A dynamic analysis on public bus transport's supply quality by using AHP, Transport 27(3): 268-275. http://dx.doi. org/10.3846/16484142.2012.719838

Dupagne, A.; Ruelle, C.; Teller, J.; Cornelis, B. 2004. SUIT. Sustainable development of urban historical areas through an active integration within towns. Research report. Liege: LEMA, University of Liege.

Dutta, M.; Husain, Z. 2009. An application of multicriteria decision making to built heritage. The case of Calcutta, Journal of Cultural Heritage 10(2): 237243. http://dx.doi.org/10.1016/j.culher.2008.09.007

Expert. 2004. Expert Choice. Tutorials. Arlington: Expert Choice Inc.

Fairclough, G. J.; Harrison, R.; Jameson Jr. J. H.; Schofield, J. 2007. The heritage reader. English heritage. London: Routledge.

Giove, S.; Rosato, P.; Breil, M. 2010. An application of multicriteria decision making to build heritage. The redevelopment of Venice Arsenal, Journal of MultiCriteria Decision Analysis 17(3-4): 85-99. http:// dx.doi.org/10.1002/mcda.455

Girard, L. F.; De Toro, P. 2007. Integrated spatial assessment: a multicriteria approach to sustainable development of cultural and environmental heritage in San Marco dei Cavoti, Italy, Central European Journal Operational Research 15(3): 281-299. http:// dx.doi.org/10.1007/s10100-007-0031-1

Ho, W. 2008. Integrated analytic hierarchy process and its applications - a literature review, European Journal of Operational Research 186(1): 211-228. http:// dx.doi.org/10.1016/j.ejor.2007.01.004

Ishizaka, A.; Labib, A. 2009. Analytic Hierarchy Process and Expert Choice: benefits and limitations, OR Insight 22(4): 201-220. http://dx.doi.org/10.1057/ ori. 2009.10

Ishizaka, A.; Pearman, C.; Nemery, P. 2012. AHPSort: an AHP-based method for sorting problems, International Journal of Production Research 50(17): 4767-4784. http://dx.doi.org/10.1080/00207543.2012 657966

Jokilehto, J. 2005. A history of architectural conservation. Oxford: Elsevier.

Kaklauskas, A.; Kelpšienė, L.; Zavadskas, E. K.; Bardauskienè, D.; Kaklauskas, G.; Urbonas, M.; Sorakas, V. 2011. Crisis management in construction and real estate: conceptual modeling at the micro-, meso- and macro-levels, Land Use Policy 28(1): 280-293. http://dx.doi.org/10.1016/j.landusepol.2010.06.008

Kilincci, O.; Onal, S. A. 2011. Fuzzy AHP approach for supplier selection in a washing machine company,
Expert Systems with Applications 38(8): 9656-9664. http://dx.doi.org/10.1016/j.eswa.2011.01.159

Kim, C. J.; Yoo, W. S.; Lee, U. K.; Song, K. J.; Kang, K. I.; Cho, H. 2010. An experience curve-based decision support model for prioritizing restoration needs of cultural heritage, Journal of Cultural Heritage 11(4): 430-437. http://dx.doi.org/10.1016/j.culher.2010.03.004

Kull, T. J.; Talluri, S. 2008. A supply risk reduction model using integrated multicriteria decision making, IEEE Transactions on Engineering Management 55(3): 409-419. http://dx.doi.org/10.1109/ TEM.2008.922627

Kutut, V.; Zavadskas, E. K.; Lazauskas, M. 2014. Assessment of priority alternatives for preservation of historic buildings using model based on ARAS and AHP methods, Archives of Civil and Mechanical Engineering 14(2): 287-294. http://www.sciencedirect. com/science/article/pii/S1644966513001386

Labib, A. W. 2011. A supplier selection model: a comparison of fuzzy logic and the analytic hierarchy process, International Journal of Production Research 49(21): 6287-6299. http://dx.doi.org/10.1080/002075 43.2010 .531776

Lee, A. H. I. 2009a. A fuzzy AHP evaluation model for buyer-supplier relationships with the consideration of benefits, opportunities, costs and risks, International Journal of Production Research 47(15): 42554280. http://dx.doi.org/10.1080/00207540801908084

Lee, A. H. I. 2009b. A fuzzy supplier selection model with the consideration of benefits, opportunities, costs and risks, Expert Systems with Applications 36(2): 28792893. http://dx.doi.org/10.1016/j.eswa.2008.01.045

Levary, R. R. 2008. Using the analytic hierarchy process to rank foreign suppliers based on supply risks, Computers and Industrial Engineering 55(2): 535-542. http://dx.doi.org/10.1016/j.cie.2008.01.010

Mafakheri, F.; Breton, M.; Ghoniem, A. 2011. Supplier selection-order allocation: a two-stage multiple criteria dynamic programming approach, International Journal of Production Economics 132(1): 52-57. http://dx.doi.org/10.1016/j.ijpe.2011.03.005

Mebratu, D. 1998. Sustainability and sustainable development: historical and conceptual review, Environmental Impact Assessment Review 18(6): 493-520. http://dx.doi.org/10.1016/S0195-9255(98)00019-5

Moffett, A.; Sarkar, S. 2006. Incorporating multiple criteria into the design of conservation area networks: a mini review with recommendations, Diversity and Distributions 12(2): 125-137. http://dx.doi. org/10.1111/j.1366-9516.2005.00202.x

Murzyn-Kupisz, M. 2013. The socio-economic impact of built heritage projects conducted by private investors, Journal of Cultural Heritage 14(2): 156-162. http://dx.doi.org/10.1016/j.culher.2012.04.009

Nyseth, T.; Sognnaes, J. 2013. Preservation of old towns in Norway: heritage discourses, community processes and the new cultural economy, Cities 13: 69-75. http://dx.doi.org/10.1016/j.cities.2012.05.014

Ordoobadi, S. M. 2010. Application of AHP and Taguchi loss functions in supply chain, Industrial Management and Data Systems 110(8): 1251-1269. http:// dx.doi.org/10.1108/02635571011077861 
Price, N. S.; Kirby Talley, M. Jr.; Melucco Vaccaro, A. 1996. Historical and philosophical issues in the conservation of cultural heritage. Los Angeles: The Getty Conservation Institute.

Punniyamoorthy, M.; Mathiyalagan, P.; Parthiban, P. 2011. A strategic model using structural equation modeling and fuzzy logic in supplier selection, Expert Systems with Applications 38(1): 458-474. http:// dx.doi.org/10.1016/j.eswa.2010.06.086

Reza, B.; Sadiq, R.; Hewage, K. 2011. Sustainability assessment of flooring systems in the city of Tehran: an AHP-based life cycle analysis, Construction and Building Materials 25(4): 2053-2066. http://dx.doi. org/10.1016/j.conbuildmat.2010.11.041

Saaty, T. 1980. The analytic hierarchy process. New York: McGraw Hill.

Saaty, T.; Sagir, M. 2009. Extending the measurement of tangibles to intangibles, International Journal of Information Technology \& decision Making 8(1): 7-27. http://dx.doi.org/10.1142/S0219622009003247

Saaty, T.; Sagir, M. 2012. Global awareness, future city design and decision making, Journal of Systems Science and Systems Engineering 21(3): 337-355. http:// dx.doi.org/10.1007/s11518-012-5196-z

Saaty, T.; Shang, J. S. 2011. An innovative orders-ofmagnitude approach to AHP-based multi-criteria decision making: prioritizing divergent intangible humane acts, European Journal of Operational Research 214(3): 703-715. http://dx.doi.org/10.1016/j. ejor.2011.05.019

Saaty, T.; Shih, H. S. 2009. Structures in decision making: on the subjective geometry of hierarchies and networks, European Journal of Operational Research 199(3): 867-872. http://dx.doi.org/10.1016/j. ejor.2009.01.064

Sapač, I. 2012. Kaj je grad? Problematika terminološke oznake in temeljne definicije, in Preinfalk, M. (Ed.). Iz zgodovine slovenskih gradov. Ljubljana: Zveza zgodovinskih društev Slovenije, 391-412.

Sevkli, M. 2010. An application of the fuzzy ELECTRE method for supplier selection, International Journal of Production Research 48(12): 3393-3405. http:// dx.doi.org/10.1080/00207540902814355

Sivilevičius, H. 2011. Modelling the interaction of transport system elements, Transport 26(1): 20-34. http:// dx.doi.org/10.3846/16484142.2011.560366

Skoglund, P.; Svensson, E. 2010. Discourses of nature conservation and heritage management in the past, present and future: discussing heritage and sustainable development from Swedish experiences, European Journal of Archaeology 13(3): 368-385. http:// dx.doi.org/10.1177/1461957110386703

Stopar, I. 2012. Slovenski gradovi - prezrta dediščina, in Preinfalk, M. (Ed.). Iz zgodovine slovenskih gradov. Ljubljana: Zveza zgodovinskih društev Slovenije, 379-390.

Tsai, W.; Hung, S. 2009. A fuzzy goal programming approach for green supply chain optimisation under activity-based costing and performance evaluation with a value-chain structure, International Journal of Production Research 47(18): 4991-5017. http:// dx.doi.org/10.1080/00207540801932498

Tuan, T. H.; Navrud, S. 2007. Valuing cultural heritage in developing countries: comparing and pooling contingent valuation and choice modelling estimates, Environmental and Resource Economics 38(1): 5169. http://dx.doi.org/10.1007/s10640-006-9056-5

Verbič, M.; Slabe-Erker, R. 2009. An econometric analysis of willingness-to-pay for sustainable development: a case study of the Volčji Potok landscape area, Ecological Economics 68(5): 1316-1328. http://dx.doi. org/10.1016/j.ecolecon.2008.09.002

Vidal, L. A.; Marle, F.; Bocquet, J. C. 2011. Using a Delphi process and the Analytic Hierarchy Process (AHP) to evaluate the complexity of projects, Expert Systems with Applications 38(5): 5388-5405. http:// dx.doi.org/10.1016/j.eswa.2010.10.016

Vodopivec, B. 2012. Opredelitev kriterijev in podkriterijev večkriterijske metode za oceno prioritet obnove stavbne dediščine na primeru gradov $v$ Sloveniji. Študija, Ljubljana: Fakulteta za gradbeništvo in geodezijo.

Wang, H. J.; Zeng Z. T. 2010. A multi-objective decisionmaking process for reuse selection of historic buildings, Expert Systems with Applications 37(2): 12411249. http://dx.doi.org/10.1016/j.eswa.2009.06.034

Wang, T.; Yang, Y. 2009. A fuzzy model for supplier selection in quantity discount environments, Expert Systems with Applications 36(10): 12179-12187. http://dx.doi.org/10.1016/j.eswa.2009.03.018

Yang, J. L.; Chiu, H. N.; Tzeng, G. H.; Yeh, R. H. 2008. Vendor selection by integrated fuzzy MCDM techniques with independent and interdependent relationships, Information Sciences 178(21): 4166-4183. http://dx.doi.org/10.1016/j.ins.2008.06.003

Žarnić, R.; Rajčić, V.; Moropoulou, A. 2012. Identity card of cultural heritage: how to collect and organize data, in $4^{\text {th }}$ International conference on progress in cultural heritage preservation, EuroMed'12 proceedings, 340-348.

Zan, L.; Baraldi, S. B. 2013. The heritage chain management. General issues and a case study, China, Journal of Cultural Heritage 14(3): 211-218. http:// dx.doi.org/10.1016/j.culher.2012.06.007

Zavadskas, E. K.; Turskis, Z.; Ustinovichius, L.; Shevchenko, G. 2010. Attributes weights determining peculiarities in multiple attribute decision making methods, Inzinerine Ekonomika - Engineering Economics 21(1): 32-43.

Zavadskas, E. K.; Vainiūnas, P.; Turskis, Z.; Tamošaitiene, J. 2012. Multiple criteria decision support system for assessment of projects managers in construction, International Journal of Information Technology \& Decision Making 11(2): 501-502. http:// dx.doi.org/10.1142/S0219622012400135 